\title{
BENEFITS OF FINANCIAL RATIOS FOR FINANCING SHARIA BANKING INDONESIA
}

\author{
${ }^{1}$ Ahmad Habibi, ${ }^{2}$ Muhammad Iqbal \\ Faculty of Economics and Business Islamic, UIN Raden Intan Lampung \\ J1. Letnan Kolonel H. Endro Suratmin, Sukarame, Kota Bandar Lampung, 35131 \\ ${ }^{1}$ habibi@,radenintan.ac.id 2iqbalfebi@,radenintan.ac.id
}

\begin{abstract}
This study aims at how the benefits of financial ratios to Islamic banking financing in Indonesia. The data used is time-series data. Population, as well as samples in this study, are statistical reports of sharia banking Sharia Commercial Banks in Indonesia for the period January 2015 December 2017. Ratio selection is conducted by using a stepwise regression method as well as hypothesis testing is done by multiple regression, $\mathrm{t}$-test, and $\mathrm{F}$ test. The results obtained from the study show that the value of Adjusted R2 can obtain values of 0.914 or $91.40 \%$. The t-test results show that FDR, NPF, and ROA significantly influence Sharia Banking Financing. This shows that from the financial ratios used in this study, three financial ratios that affect the Financing of Sharia Banking in Indonesia, namely FDR, NPF, and CAR.
\end{abstract}

Keywords: Financial Ratios, Financing, and Shariah Bankin

\section{Introdaction}

Financing is the provision of money or an equivalent bill based on an agreement between banks and other parties being financed to return the money or bill after a certain period of time in exchange for profit sharing (Muhammad, 2004).

Many factors influence banks in channeling to see the internal condition of the company, usually the bank refers to the bank's financial statements which are indicated by the will was accommodated by the issuance of various financial ratios. The internal condition Law No.7 of 1992 concerning banking which of the company is seen from several financial introduced two national banking systems, ratios. In this study, the independent variable conventional and sharia as well as a dual 
banking system. Then it was followed by the issuance of Law No. 10 of 1998, which explicitly explains that there are two banking systems in the country (dual banking system), namely the conventional banking system and the sharia banking system that allows banks to operate fully Syariah or by opening sharia business units (UUS). This process implies the issuance of Law No. 21 of 2008 concerning Islamic banks in which Islamic banks have their legal (Indonesia, 2012)

Distribution of financing as the core business of Islamic banking plays an important role in operational activities. Through financing activities, banks can generate profitability and develop their businesses. The purpose of financing is not just to increase the profit but also to enlarge expediency so that its main objective is to meet the interests of stakeholders, namely for bank owners, employees, the public (both debtors and fund owners) for the government (state) and the bank concerned.

Indonesia is a country with a population reaching 255,461.7 million in 2015 (Nasional, 2018) Also Besides, as the country with the largest Muslim population in the world where around $85 \%$ of its population is Muslim, Indonesia should be able to become a center for the development of Islamic finance, especially Islamic banking.

This can be a significant opportunity for the development of Islamic banking in Indonesia. One of the supports regarding Islamic banking in Indonesia is the issuance of a law concerning the implementation of Islamic Banking activities, namely Law No.21 of 2008 concerning Islamic Banking (Nomor, 21 C.E.). The growth of Islamic banking in Indonesia has experienced a fairly good development but not too significant, this can be seen from the data presented, as follows:

Table 1. Number of Sharia Banks in Indonesia in 2013-2017

\begin{tabular}{|l|r|r|r|r|r|}
\hline $\begin{array}{r}\text { Sharia } \\
\text { Banks }\end{array}$ & $\mathbf{2 0 1 3}$ & $\mathbf{2 0 1 4}$ & $\mathbf{2 0 1 5}$ & $\mathbf{2 0 1 6}$ & $\mathbf{2 0 1 7}$ \\
\hline BUS & 11 & 12 & 12 & 13 & 13 \\
\hline UUS & 23 & 22 & 22 & 21 & 21 \\
\hline BPRS & 158 & 163 & 163 & 166 & 167 \\
\hline
\end{tabular}

Source: SPS Perbankan Syariah, 2017.

From the data table, it can be seen that the number of Islamic Banks in Indonesia in 2013 is 11 of BUS and in 2014 and 2015 increased to 12 BUS and in 2016 and 2017 increased to 13 BUS, while the Sharia Business Unit reduced in 2015 amounted to 22 UUS to 21 UUS in October 2016 with the conversion of PT. Bank Aceh to a Sharia Commercial Bank under the name of PT. Bank Aceh Syariah. The number of BPRS increased to 167 BPRS in 2017 (Keuangan, 2017)

From the number of Islamic banks and the market share of Islamic banking in Indonesia, it can be seen that when compared to the total Muslim population in Indonesia, it is still under the number of conventional banks, even it is 
market share has not reached $5 \%$. This is still a challenge for Islamic banks to continue to make improvements both internally and externally. The development of financing on BUS in Indonesia can be seen from the following table:

Tabel 2. Sharia Commercial Bank Financing for 2014-2017

\begin{tabular}{|r|r|r|}
\hline Year & $\begin{array}{r}\text { Profit-Shari } \\
\text { Funding }\end{array}$ & $\begin{array}{r}\text { Receivables } / \\
\text { Murabaha and } \\
\text { Istishna }\end{array}$ \\
\hline $\mathbf{2 0 1 4}$ & 64.578 & 123.977 \\
\hline $\mathbf{2 0 1 5}$ & 76.514 & 126.838 \\
\hline $\mathbf{2 0 1 6}$ & 94.751 & 145.183 \\
\hline $\mathbf{2 0 1 7}$ & 119.689 & 157.926 \\
\hline
\end{tabular}

Source: (Keuangan, 2017)

From table 2 above, both the increase and decrease in financing show the ability of Islamic banks to maintain their business balance. Based on profit-sharing financing, it aimed at a very significant increase from $64,578.01$ billion in 2014 to $119,689.53$ billion in 2017. While receivables also increased from 2014 to $123,977,37$ billion to $157,926.54$ billion and constituted the largest amount of funds distributed to the public. Rental finance tends to decrease by $11,621.33$ billion in 2014 to $9,233.26$ in 2017. In general, the amount of funding disbursed to the public has increased from year to year, to $286,849.34$ billion in 2017 .

Banking operations must be carried out effectively and efficiently to optimize returns for the company. By looking at the benefits obtained, the performance and success of a bank can also be assessed. A good performance of Islamic banks is very important to be maintained and improved because it can reflect its trust and encourage its development, and by maintaining banking performance, it can maintain its survival.

This research is intended to further test empirical findings regarding financial ratios, especially those concerning their use in predicting factors that influence the amount of financing or funds channeled to the public by Islamic banks. Based on the background above, the formulation of the problem of this study is what ratio has a significant effect on the financing of Islamic banking in Indonesia with the stepwise regression method?

\section{The Previous Studies}

Some of the scientific works that are related to the Stepwise Regression method, including Research conducted by Mas'ud Machfoedz entitled Financial Ratio Analysis and the Prediction of Earning Changes in Indonesia. It examines predictions of earning changes using financial ratios. Samples taken from 66 manufacturing companies listed on the Jakarta Stock Exchange and the study analyzed 47 financial ratios. The results show that there are 13 significant financial ratios in predicting changes in profit for one year to come. The significant ratio consists of one ratio of shortterm liquidity category, one-term long-term solvency category, three categories of profitability ratio, one productivity category 
ratio, one indebtedness category ratio, two leverage category ratios, one ratio of return-oninvestment category and two ratios of equity categories (Machfoedz, 1994).

Another research conducted by Nur Fadjrih Asyik, entitled "The Ability of Financial Ratios in Predicting Profits (Determination of Financial Ratios as Discriminators)". The data used are ones available in the 1995 and 1996 financial statements which were published in manufacturing companies listed on the Jakarta Stock Exchange and the samples were determined by purposive sampling. The analytical tool used is discriminator analysis which is used to identify financial ratios that can distinguish changes in earnings. The purpose of the analysis is to determine financial ratios that are very efficient in distinguishing changes in earnings. There are five significant ratios, namely dividends / net income, sales / total assets, long term debt / total assets, net income/sales, and investment in property, plant, and equipment/total uses. The ratio of dividends / net income is the most discriminant ratio, while the ratio of investment in property, plant, and equipment/total uses is the least discriminant (Asyik \& Soelistyo, 2000).

Another study was conducted by Agus Endro Suwarno entitled "The Benefits of study entitled The Effect of Interest Rates and Information on Financial Ratios in Predicting Profit Changes (Empirical Study of Public Manufacturing Companies in the Jakarta Stock Exchange). The data used are time-series and pooled time-series data. The study uses purposive sampling with a sample of 42 manufacturing companies for predicting earning changes in 2000, a sample of 39 manufacturing companies for predicting changes in 2001, and a sample of 49 manufacturing companies for predicting earning changes in 2002. Ratio selection is conducted by using a stepwise regression method, hypothesis testing by using multiple regression, $\mathrm{t}$-test, and F-test. The results obtained from the study show the first hypothesis that the 1999 financial ratios are significant to predict changes in earnings in 2000. These financial ratios are long-term liabilities to shareholders' equity, operating profit to profit before taxes, and net income to sales. The second hypothesis results show three significant financial ratios to predict changes in earnings in 2001, namely inventory to working capital, net income to net worth, operating profit to profit before taxes, while the ratio of cost of goods sold to net sales is not significant. The third hypothesis shows that the financial ratio of operating profit before taxes and profit after taxes to fixed assets is not significant to predict changes in earnings in 2002 (Suwamo, 2004).

Much research on sharia banking has been carried out, M. Ghafur Wibowo conducted a Total Profit Sharing on Mudharabah Volumes at BMI 1994-2001 proving that only real public income has a positive and significant effect on mudharabah volumes. While the two other 
variables, namely interest rates and the amount of profit-sharing does not significantly influence to it (Wibowo, 2003).

Based on the results of previous studies and the problems raised, then as a reference to formulate the following hypothesis, a theoretical framework is presented in the research model as shown in the following figure:

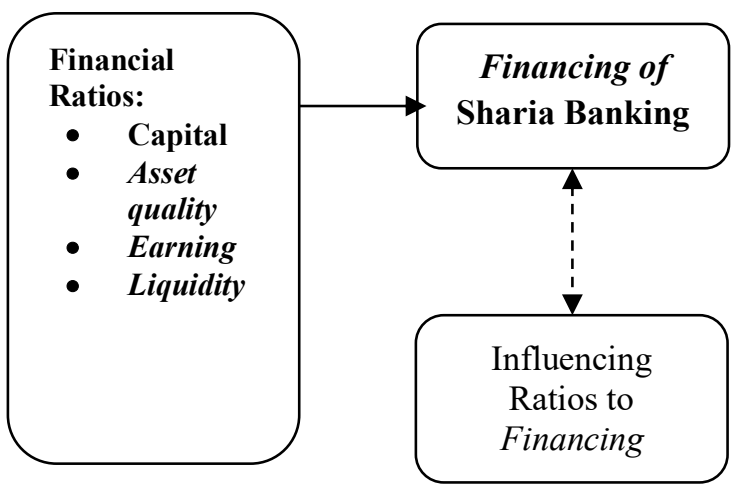

Figure 1. Theoretical Framework

\section{Hypothesis}

The hypothesis proposed in this study is as follows:

Ho: Financial ratios have no significant effect on

Islamic banking financing in Indonesia.

Ha: Financial ratios have a significant effect on Islamic banking financing in Indonesia.

\section{Method of Research}

This research is included in quantitative research. It is associative, which is a research method used to find the relationship between one variable and another and to test and use the truth of a problem or knowledge. In this study research data using time series data. In this study quantitative, the data used are Sharia Banking Statistics of Sharia Commercial Banks for the period January 2015 to December 2018. Sources of data used in this study are secondary data. In this case, the researchers obtained secondary data from Sharia Banking Statistics of Sharia Commercial Bank reports published by the Financial Services Authority.

The population in this study is the Islamic Banking Statistics of Bank of Indonesia Monthly Banking Statistics Report. The sample in this study is the Islamic Banking Statistics Report Sharia Commercial Banks Monthly period from January 2015 to December 2017. The dependent variable in this study is Financing. Financing in this study is funds channeled by banks to the public in the form of profit-sharing based financing. The independent variables used in this study are Capital, Asset quality, Profitability and Liquidity Analysis of the data used in stepwise regression. Stepwise regression involves two types of processes: forward selection and backward elimination. This technique is carried out through several stages. At each stage, we will decide which variable is the best predictor to be included in the model (Ghozali, 2018).

\section{Discussion}

\section{Agent Theory}

Agency theory was put forward by (Meckling \& Jensen, 1976) The relationship between owner and manager is referred to as an agency relationship. It is a contract in which one or more people (called principals) involve 
another person (called an agent) to perform some services on their behalf which include the delegation of some decision-making authority to the agent. So, the so-called principals, in this case, are the shareholders and the so-called agents are the managers who manage the company.

Agency problems occur in companies where managers own less than one hundred percent of the company's shares. In manufacturing companies, an agency problem potentially occurs because the proportion of company ownership by managers is relatively small.

Another potential conflict in a company is between creditors (debt holders) and shareholders. It is possible because creditors feel that they have been exploited by shareholders in investment financing, all of which come from debt. If the investment is successful, most of the profits will be the right of shareholders, but if the company fails or goes bankrupt then the risk is also felt by creditors.

Conflicts of interest between managers, shareholders, and creditors can be minimized by a supervisory mechanism that can align with the interests of related parties. But by the emergence of the supervisory mechanism, it will cause costs called agency costs (agency costs) (Lukman, 2008). According to Horne and Wachowicz agency costs are usually associated with management supervision to ensure that management acts consistently by following by under the company's contractual agreements with creditors and shareholders. Anyone who incurs supervision costs, the costs incurred must be borne by shareholders (Horne \& Wachowicz, 2012).

Agency costs include monitoring costs, bonding costs, and residual loss.

1. 1. Monitoring costs are costs incurred by shareholders (principal) to supervise so that the manager (agents) carries out all activities by following by under the agreed contract. For example, audit fees and costs for establishing manager compensation plans, budget restrictions, and compensation rules.

2. 2. Bonding costs are costs incurred by management to convince shareholders that management carries out all company activities according to the contract or meets the interests of shareholders. For example, the availability of managers to hire auditors to audit their company's financial statements. Or to guarantee that principals provide compensation if the agent carries out compliance with his contract.

3. 3. Residual loss is the cost arising from the fact that the agent's actions are sometimes different from those that maximize the principal's interests.

The agency problem monitoring mechanism also has an important role, namely oversight by institutional ownership. It is related to the actions of institutional investors to protect the value of investments that they invest in the 
company because outside equity holders will always oversee the actions of managers to ensure that they do not take actions that are contrary to the interests of shareholders. Furthermore, the bonding mechanism is carried out by increasing the company's shareholdings by management with higher ownership. This will reduce conflicts between shareholders and managers, but it can also be done by increasing debt. reduce manager and shareholder conflicts (Nurfauziah, Harjito, D. A., Ameliawati, 2007).

\section{Stewardship Theory}

Stewardship theory emerged together with the development of accounting. Stewardship theory is based on psychological and sociological theories and originates from management accounting thinking, where stewards are motivated to behave according to the wishes of the principal. Stewardship theory is a description of the condition of managers who are motivated by the main outcome of the organization's interests, not motivated by their interests (Donaldson \& Davis, 1989).

Stewardship theory explains that shared interests are the basis for a manager's actions. If there are differences in interests between the principal and steward, then the steward will try to cooperate because they act in accordance with the principal's actions and for the common interest it can be a rational consideration to achieve common goals. The important thing in stewardship theory is that managers align their goals according to Principal goals, but that does not mean that stewards do not have needs (Rahardjo, 2007).

Stewardship theory is built on philosophical assumptions about human nature, namely that humans are intrinsically trustworthy, able to act responsibly, have integrity and honesty with others. This is a relationship based on the trust that shareholders desire. In other words, the Stewardship theory views management as a party that can be trusted to act in the best possible way for the public and shareholders' interests. The application of the Stewardship theory in this study is based on the relationship of trust and honesty between the bank and the customer in distributing murabahah financing so that it will achieve the expected goals.

\section{Research and Findings}

Analysis of the data used in stepwise regression. Variables are determined based on the F-test; variables are added to the model as long as the $p$-value is less than the critical value $\alpha$ (usually 0.05). Then the variable with a pvalue more than the critical value $\alpha$ will be removed. The stepwise regression test results can be described as follows: 
Table 3

Summary of Study

\begin{tabular}{|l|r|r|r|}
\hline Variable & Coefficient & t & Sig \\
\hline (Constant) & 15,305 & 45,491 & 0,000 \\
\hline Financing & & & \\
\hline FDR & $-0,042$ & $-10,089$ & 0,000 \\
\hline NPF & $-0,074$ & $-3,005$ & 0,005 \\
\hline ROA & $-0,116$ & $-2,384$ & 0,023 \\
\hline $\begin{array}{l}\text { F-counting } \\
=124,641\end{array}$ & & & \\
\hline $\begin{array}{l}\text { Significatio } \\
=0,000\end{array}$ & & & \\
\hline $\begin{array}{l}\text { Adjusted } \\
0,914\end{array}$ & & & \\
\hline $\begin{array}{l}\text { R Square } \\
0,921\end{array}$ & & & \\
\hline
\end{tabular}

Source: secondary data from 2017.

Based on the results of the simultaneous significance test ( $\mathrm{F}$ test), it states that the value of F-count is 124,641 and the significance value is 0,000 , which means that the FDR, NPF, and ROA variables simultaneously affect Sharia Banking Financing in Indonesia. While the Adjusted R2 determination coefficient test results, it obtained a value of 0.914 or $91.40 \%$ which means that the value of $91.40 \%$ variation Financing can be explained by the variables FDR, NPF, and ROA while the remaining $8.60 \%$ is explained by other variables that are not in the Stepwise model Regression. Islamic banks are financial institutions that depend heavily on public trust.
Assessments made on the performance of banks are needed to see how efficiently and effectively the use of resources owned for the development and survival of the company. Through financial ratio analysis, the performance of a bank from the financial side can be known. Financing to Deposit Ratio (FDR) is a comparison between financing provided by a bank and third party funds successfully mobilized by a bank. How much funding is given to the public or customers, banks must be able to compensate by immediately meeting the need for the withdrawal of funds at any time by the depositor? FDR is defined as a comparison between financing provided and funds received by banks. This FDR is one of the long term liquidity ratios of banks. Based on the understanding of the experts above, it can be concluded that the Financing to Deposit ratio (FDR) is a ratio that illustrates the level of ability of Islamic banks in returning funds to third parties through the profits derived from Mudharabah financing.

Ratio in conventional banks, the difference in mentioning this is because in Islamic banks there is no such thing as a loan or loan, but called financing. Banks are said to be liquid when they can meet all of their debt obligations and meet the demand for funds raised by customers without any delay in providing funds through these financing. Thirdparty funds, which are the largest composition of 
funds contained in Islamic banks, have a very important function for national Islamic banking institutions. Because DPK is the main $\operatorname{cog}$ in sharia banking in carrying out its function as an intermediary institution.

The increase in the value of FDR based on stewardship theory shows that the bank will manage the funds for financing that are mobilized to customers. Managers in this case act as stewards for managing funds from the public, if the higher loan funds originating from third-party funds, the financing made by the bank will also be high. So it can be said that FDR affects Islamic bank financing

Non-Performing Financing (NPF) is a ratio that arises due to problematic financing originating from funds channeled by Islamic banks. In the case of Islamic bank financing risks have a greater risk compared to other risks that exist in Islamic banks. Problem financing in Islamic banks is indicated by the NPF indicator by looking at the NPF level. If the NPF value is high then the risk of Islamic bank financing is also high. While the profits to be obtained by Islamic banks will decrease due to the nonpayment of both principal installments and profits from the financing paid.

The higher NPF level indicates a high risk of financing and will reduce the profitability of a bank. In channeling funds to the public, the bank can carry out stages in the provision of financing to the public so that the financing provided is right on target and can provide benefits to banks. This needs careful planning in the management of banking financing. Problem financing in Islamic banks cannot be avoided. The existence of problematic financing will cause losses for banks where not only loan funds do not return, but banks also have to pay costs to cover losses due to non-payment of loans by debtors which will ultimately reduce the level of bank profits, due to reduced margin income or profit-sharing that becomes main income of Islamic banks. The existence of problematic financing or problem loans at banks will make banks have to provide Allowance for Earning Asset Losses (PPAP) to anticipate to cover losses arising from the presence of problem financing.

According to Agency Theory, Agency Problems arise because of the asymmetry of information, which is nothing but a condition where information of information is involved in transaction activities. That's where a contract is needed to minimize information asymmetry. The information asymmetry itself can result in losses for the lender (the bank). The problem that results in the high level of Non-Performing Financing (NPF) or bad credit is the inability of the customer to meet the requirements, one of the parties violating the credit contract that was agreed at the beginning of the agreement or in other words, the problem of the principal-agent. The higher the Non-Performing Financing (NPF), the higher the risk faced by the Bank, so that it can cause fewer opportunities for banks to 
earn income and result in a decrease in the distribution of financing to customers.

Return On Assets (ROA) is a comparison between net income and average assets. ROA can also be interpreted as a ratio that illustrates the ability of banks to generate profits from the assets used(Iqbal, 2018). The greater the ROA of a bank is, the greater the level of profit achieved by the bank and the better the bank's position in terms of asset use (Muhammad, 2004) ROA has a negative and significant effect on financing. This happened because the calculation of ROA was obtained from the profit of the current year which still did not take into account the taxation aspects. Generally, with a large profit, the tax consequences that are borne will also be large, so that the bank still has to meet these large tax obligations and not to mention the profits obtained by Islamic banking are not fully distributed for profit-sharing agreements, but the bias is still allocated to savings products mudharabah or other Islamic banking operational needs.

Stewardship theory is a theory built on a philosophical assumption about human nature, namely that humans are intrinsically trustworthy. In connection with the stewardship theory, it can be understood that in this case, the manager as a steward is responsible for managing funds from customers. The trust given by the bank to the customer in the hope that the customer will act according to the objectives at the beginning of the agreement when the contract starts so that both Islamic banks and customers can benefit. So, the benefits obtained from the financing provided will become income and will increase the profit of Islamic banks so that financing will increase

\section{Conclusion}

Based on the formulation of the problem, hypothesis testing and discussion of the variables in this study, it can be concluded that the results of the calculation of the coefficient of determination test or Adjusted R2 obtained values of 0.914 or $91.40 \%$. The F statistical test aims to show whether all the independent variables included in the regression model have a joint effect on the independent variable. Based on the ANOVA test or the F test performed on the FDR, NPF and ROA variables on the Financing variable, a Fount value obtained 124,641 with a significance of 0,000 . The t-test results show that FDR, NPF, and ROA significantly influence Sharia Banking Financing. This shows that from the financial ratios used in this study, three financial ratios that affect the Financing of Sharia Banking in Indonesia, namely FDR, NPF, and CAR.

Based on the results of the conclusions in this study, for academics and banking practitioners, with the existence of this research, it can be used as one of the references or sources of reference related to banking financial management and in terms of solving problems 
related to the influence of financing on Islamic banks.

\section{Reference}

Asyik, N. F., \& Soelistyo, S. (2000). Kemampuan Rasio Keuangan dalam Memprediksi Laba (Penetapan Rasio Keuangan Sebagai Discriminator). Journal of Indonesian Economy and Business, 15(3), 313-331.

Donaldson, L., \& Davis, H. J. (1989). Ceo governance and shareholder returns: Agency theory or stewardship theory [paper presented at annual meeting of the Academy of Management, Washington, DC]. Donaldson Washington, DC.

Ghozali, I. (2018). Aplikasi analisis multivariete dengan program IBM SPSS 23.

Horne, J. C. Van, \& Wachowicz, J. M. (2012). Prinsip-prinsip manajemen keuangan. Jakarta: Salemba Empat.

Indonesia, B. (2012). Direktorat Perbankan Syariah Bank Indonesia. Kajian Model Bisnis Perbankan Syariah, Jakarta: Bank Indonesia.

Iqbal, M. (2018). Pengaruh Asean Economic Community (AEC) Terhadap Kinerja Perbankan Syariah Di Indonesia. AlAmwal: Jurnal Ekonomi Dan Perbankan Syari'ah, 10(2), 158-168. https://doi.org/10.24235/amwal.v10i2.336 1
Keuangan, O. J. (2017). Statistik Perbankan Syariah. 2016. Tersedia: Www. Ojk. Go. Id.[Diakses 28 September 2018].

Lukman. (2008). Pengaruh Kepemilikan Manajerial, Kepemilikan Institusional, dan Dividen Terhadap Kebijakan Utang Pada Perusahaan Yang Terdaftar Di Bursa Efek Jakarta. Wacana Ekonomika, 6(1).

Machfoedz, M. (1994). Financial ratio analysis and the prediction of earnings changes in Indonesia. Kelola, 7(3), 114-134.

Meckling, W. H., \& Jensen, M. C. (1976). Theory of the firm: Managerial behavior, agency costs and ownership structure. Journal of Financial Economics, 3(4), $305-360$.

Muhammad, H. M. S. (2004). Manajemen dana bank syariah. Ekonisia.

Nasional, B. P. P. (2018). Jumlah Penduduk Indonesia. Jakarta.

Nomor, U.-U. (21 C.E.). tahun 2008 tentang Perbankan Syariah.

Nurfauziah, Harjito, D. A., Ameliawati, H. . (2007). No Hubungan Kepemilikan Manajerial, Kepemilikan Institusi dan Kebijakan Utang dalam Perspektif Masalah Agensi Di IndonesiaTitle. VENTURA, 10(1).

Rahardjo, B. (2007). Keuangan dan Akuntansi untuk Manajer Non Keuangan. Yogyakarta: Graha Ilmu. 
Suwamo, A. E. (2004). MANFAAT INFORMASI

RASIO KEUANGAN DALAM

MEMPREDIKSI PERUBAHAN LABA

(Studi Empiris Terhadap Perusahaan

Manufaktur Go Publik Di Bursa Efek

Jakarta). Program Pasca Sarjana

Universitas Diponegoro.

Wibowo, M. G. (2003). Pengaruh Suku bunga dan Jumlah bagi hasil terhadap Volume Mudhārabah di BMI tahun 1994-2001. Jurnal Muamalah, I. 